\title{
Bank Reporting in the Context of Sustainable Development
}

\author{
Submitted 20/08/19, 1st revision 18/09/19, 2nd revision 23/10/19, accepted 20/12/19
}

\begin{abstract}
O.G. Semenyuta ${ }^{1}$, K.V. Dudko ${ }^{2}$
Abstract:

Purpose: The article is devoted to the transformation of the activities of Russian commercial banks under the influence of the concept of sustainable development. The article is supposed to explore the potentials of banks in the conditions of sustainable economic development and to identify the development directions of the reports published by banks.

Methodology/Approach: To achieve this goal, firstly, we need to describe the essence of the concept of sustainable development and the challenges facing the Russian economy that impede the more active promotion of the values of this concept in Russia. Secondly, we need to consider the main currently existing initiatives that promote the sustainable development goals and reporting published by Russian commercial banks in the context of sustainable development, and thirdly, to describe the directions for the formation of reporting by banks in the framework of achieving the sustainable development goals through principles and criteria, essential for an objective assessment.

Findings: The problem of sustainable development, the spur for the emergence of which was the concept of sustainable development, as a factor in assessing the state of banking activity has been actively studied. In this regard, the authors sequentially studied the reporting published by the largest banks in Russia in terms of assets, highlighted the problems in the formation of reports by commercial banks regarding sustainable development and presented the principles and criteria for its formation.

Practical implications: The results of this research can be involved in the process of systematization of the results of the activities of Russian banks in achieving sustainable development goals in the framework of bank reporting.

Originality/Value: The main contribution of this article lies in the fact that the study of the problems of bank reporting in the context of economic, environmental and social sustainability presented in the scientific literature is based on standard appraisal forms without focus on the goals of implementing the concept of sustainable development.
\end{abstract}

Keywords: Banking, sustainable development concept, reporting, principles, criteria.

JEL Code: G21, Q01

Paper type: Research article

\footnotetext{
${ }^{1}$ Doctor of Science (Economics), Associate Professor and Head of the Department of Banking, Rostov State University of Economics, Rostov-on-Don, ogsmail1@mail.ru

${ }^{2}$ Postgraduate, Rostov State University of Economics, Rostov-on-Don, kseniya.dudko3@yandex.ru
} 


\section{Introduction}

The sustainable development concept was formed as a result of combining three business activity areas: economic, environmental, social. Herewith it is important to understand that the goal of any commercial activity, including banking, is profit-making; accordingly, this indicator is an important condition for the development of a modern bank. The implementation of the sustainable development concept at the country or regional level should, on the one hand, promote the use of emerging development opportunities and, on the other hand, help to overcome emerging problems.

In general, the concept is expressed in ensuring harmony between economic growth subject to financial sustainability and broad social aspects oriented environmental improvement, and in supporting effective management (Bobylev and Perelet, 2013). Special focus on human factor's role is important because it is individuals who are responsible for the vitality of the sustainable development concept and, therefore, should understand it well enough and have adequate tools for implementation of its principles. Without a doubt, Russia is a country with a huge social and economic potential, including natural resources. Changes in the natural environment of Russia have an impact on the entire global ecosystem; and it means that promoting the sustainable development concept in Russia benefits the world community (Semenyuta, 2017).

The implementation of the concept in question, in accordance with international standards, faces many difficulties and obstacles. One of them is the Russian mentality and political culture that have not developed respect for the environment in society and formed principles of the socially responsible business. It should be noted that Russian business leaders see the sustainable development concept as vague and unclear, which significantly complicates the possibilities of its implementation. Therefore, in modern Russia, the basic premises of the sustainable development concept are being adopted by slow degrees (Semenyuta and Dudko, 2015). The key challenges of sustainable development in Russia, both now and in the long term, are:

- increasing competitiveness in world markets through the introduction of innovative systems;

- population aging as a load on the social system;

- migration processes;

- climate change;

- air pollution;

- degradation of ecosystems;

- provision of food resources;

- increase in demand for electricity in Russia and the world;

- hazardous waste amount increasing;

- accumulated waste disposal. 


\section{Materials and Methods}

\subsection{Current Trends and Requirements of the Global Community}

Turning to the general theoretical conditions of the problem under consideration, it is important to note that in September 2015 in New York, the heads of 193 Member States of the United Nations adopted 17 new Sustainable Development Goals (or SDGs) aimed at sustainable development, prosperity, the implementation of inclusion and maintaining stability around the world (The Sustainable Development Goals, 2015). The Sustainable Development Goals cover a wide range of problems related to the achievement of performance benchmarks aimed at the implementation of economic and universal human values.

Around the world, sustainability principles are increasingly included on the agenda of financial institutions and regulatory authorities (Issakova et al., 2017). Work programs are increasing in number, and the first evidence of much-needed capital redistribution appears. Foreign markets are the good example. Thus, the Climate Bonds Initiative reported that green bond issuance is 41\% higher than in 2018 (Basar, 2019). The monthly green bond issue in October 2019 reached $\$ 22.8$ billion, and the total issue since the beginning of the year is $\$ 210.8$ billion (Basar, 2019), and by the end of the year, the issue may reach $\$ 250.0$ billion (Holder, 2019).

Sean Kidney, Chief Executive Officer of the Climate Bonds Initiative, claimed that the current European Union green economy regulations currently being proposed could play a key role in reaching $\$ 1$ trillion in green bonds of annual output by the beginning of the 2020s. According to him, recommendations contributing to a more active promotion of green funding can help direct much-needed financial assets to mitigate climate change, sustainability and adapt to changes (Holder, 2019). We can see that one of the keys to increasing engagement in achieving the Sustainable Development Goals is the role of government bodies in shaping markets, including key development banks.

An additional point is that there has been an impressive increase in the number and scope of international initiatives that allow sharing experiences, stimulating action and promoting cooperation in formulating general rules and standards for sustainable development. Structurally significant initiatives include United Nations Environment Programme (UNEP), Principles for Responsible Investment, G20's GFSG (Green Finance Study Group) with UNEP as the Secretariat.

\subsection{The Principles of Banking Business in the Context of Sustainable Development Concept}

Generalizing international experience, it should be noted that in the fact that twothirds of global finance are provided by banking institutions, determining the role and responsibility of the banking industry in achieving sustainable development is one of 
the most important tasks (World Bank Group, 2018). In the process of building a sustainable development model, banks are reviewing goals and existing business models to bring the sector in line with the SDGs and the Paris Climate Agreement and other standards, programs and initiatives. In order to step up actions towards sustainable development, the leading banks and the UN released the Principles for Responsible Banking on September 22, 2019 (see Figure 1) (UN PRI, 2019).

Banks that have signed under these principles have stated that they believe that their customers, clients and companies can be prosperous "only in an inclusive society based on human dignity, equality and sustainable use of natural resources" (Dettling, 2019). UN Secretary-General António Guterres said: "The UN Principles for Responsible Banking are a guide for the global banking industry that allows it to respond, stimulate and capitalize upon a sustainable development economy. The Principles create answerability, which can implement responsibility, and ambitions, which can stimulate action" (Dettling, 2019).

According to Inger Andersen, Executive Director of UNEP, the banking industry, which plans risks associated with climate change and other environmental problems, can not only stimulate the transition to a low-carbon and climate-change-resilient economy, but also benefit from it (Dettling, 2019; Rupeika-Apoga et al., 2019).

In the context of the active promotion of the values of the concept of sustainable development throughout the world in the activities of banks through the creation and adoption of various agreements formulating guidelines, it is advisable to determine the following key indicators necessary for banks to report on sustainable development in order to achieve an objective assessment of them:

1. Financial sustainability and capacity based on official financial statements, in accordance with the requirements of Russian Accounting standards (RAS) and IFRS.

2. Features of Corporate Social Responsibility (social criterion) in the context of a bank's internal and external policy:

$\circ$ internal - provision of personnel of credit institutions, also with social benefits and preferences, indicators formed as part of personnel reporting;

- external - charitable and socially oriented activities of banks, support of various population groups, social programs.

3 Environmental Impact Assessment (environmental criterion) based on internal factors (waste management policy, etc.) and external (providing funding for projects in the field of environmental support). 
Figure 1. The Principles for Responsible Banking (UN PRI, 2019).

Principle 1: Allignment. Development of the business strategy of the bank around the needs of people and the goals of society, in accordance with the SDGs, the Paris Climate Agreement and relevant national standards/documents.

Principle 2: Impact and Target settings. Goals settings for constant increase of the positive impact, while reducing the negative impact on people and the environment and the associated risks arising from the activities of the bank, products and services.

Principle 3: Clients. Implementing responsible work with bank customers to promote sustainable methods and provide economic activity that creates common prosperity for current and future generations.

Principle 4: Stakeholders. Active and responsible consultation, interaction and cooperation with relevant parties concerned in order to achieve the goals of the society.

Principle 5: Governance and Culture. Implementation of a bank's commitment to these principles through effective management and a culture of responsible banking.

Principle 6: Transparency and Accoutability. Implementation of periodic verification of individual and collective implementation of the principles under consideration and transparency in relation to the positive and negative consequences of the bank and its contribution to the achievement of the goals of the society and bearing responsibility for them.

\section{Results}

The goals for the sustainable development of the banking system in Russia have always been relevant, and with the adoption of the SDGs, they have gained special significance. If we talk about the nature of the development and functioning of the banking system of Russia at the present time, it should be noted that most of the assets of the entire banking system of the country belong to only 5 banks, and about more than a half of the total number of operating credit companies of Russia account for only $1.5 \%$ of assets (Table 1 ).

Table 1. The ratio of the total assets of credit companies of the Russian Federation by groups as of June 1, 2019, in million rubles (CBR, 2019).

\begin{tabular}{|l|l|l|l|l|}
\hline $\begin{array}{l}\text { Distribution of credit organi- } \\
\text { zations ranked by assets }\end{array}$ & 01.01 .2018 & 01.10 .2018 & 01.01 .2019 & 01.06 .2019 \\
\hline First 5 & $47,513,821$ & $53,319,175$ & $56,865,733$ & $56,900,723$ \\
\hline From 6 to 20 & $20,007,403$ & $18,630,120$ & $19,924,791$ & $19,675,841$ \\
\hline From 21 to 50 & $9,167,982$ & $8,868,477$ & $9,230,511$ & $8,828,243$ \\
\hline From 51 to 200 & $7,195,769$ & $7,257,820$ & $7,152,776$ & $6,723,947$ \\
\hline
\end{tabular}




\begin{tabular}{|l|l|l|l|l|}
\hline From 201 & $1,306,864$ & $1,013,363$ & 909,875 & 771,768 \\
\hline Total sum & $85,191,839$ & $89,088,955$ & $94,083,687$ & $92,900,522$ \\
\hline
\end{tabular}

Figure 2. Distribution of assets of the largest Russian banks as of June 1, 2019, in \% (Rating of key performance indicators of Russian banks, 2019).

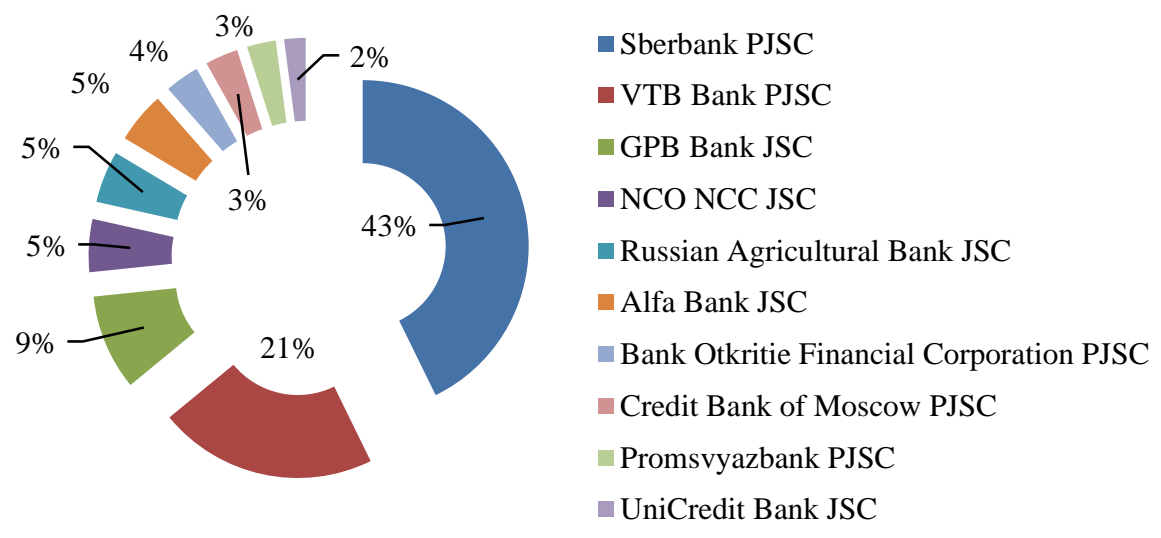

The largest banks in the top ten Russian commercial banks in terms of assets are Sberbank PJSC and VTB Bank PJSC (see Figure 2) with assets as of June 1, 2019 28,829.4 billion rubles and 14,362.7 billion rubles (Rating of indicators), respectively.

Typically, the main development trends of an industry are set and applied by structures that occupy leading positions in such an industry. In this regard, we reviewed the reports published by Sberbank PJSC and VTB Bank PJSC in the context of the concept of sustainable development.

When analyzing the reports published by Sberbank PJSC, it was found that the source of information within the framework of the principles of the concept of sustainable development until 2016 was the report on Corporate Social Responsibility (hereinafter - CSR), in which Sberbank PJSC declares its special social role, which is emphasized in the CSR report of the bank.

When considering the reporting structure of Sberbank, PJSC, it is obvious that it is transforming from 2016 to 2017, new aspects of bank business performance which are given special attention are highlighted. This trend may be attributed to the fact that that in 2017 the bank completed the implementation of the 2014-2018 Strategy with the achievement of the goals that was set in it and approved a new Development Strategy for the period of 2018-2020, the main tasks of which are to increase the scale of the business, profitability and efficiency, as well as client-focusses through the implementation of new technologies and the development of new skills of employees. 
Figure 3. Structure of the Sberbank PJSC annual report for 2017, 2018 (Sberbank PJSC Annual report, 2017; 2018).

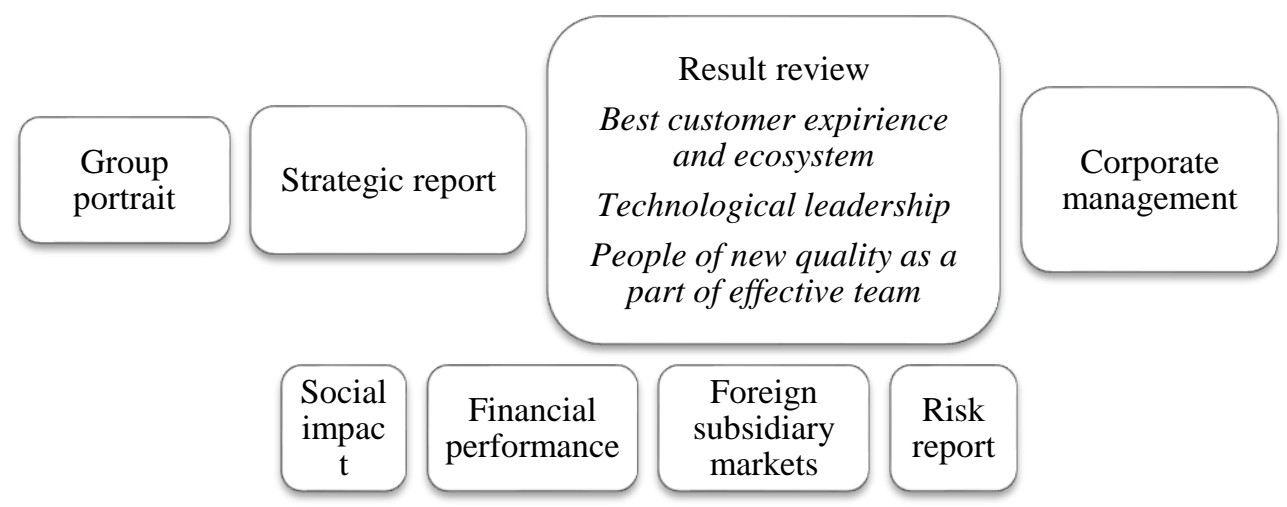

In the annual report for 2018 (see Figure 3) Sberbank PJSC emphasizes the importance of the Sustainable Development Goals adopted in 2015 by the General Assembly of the UN and notes that in its activities it is focused on 7 goals, including "promoting progressive, comprehensive and sustainable economic growth, full and productive employment and decent work, revitalization of the global partnership for sustainable development and build resilient infrastructure, promote sustainable industrialization and foster innovation" (Sberbank PJSC annual report, 2017). In the next annual report for 2018, the bank is already focusing on 10 of the sustainable development goals, including "promoting progressive, inclusive and sustainable economic growth, full and productive employment and decent work, revitalization of the global partnership for sustainable development and build resilient infrastructure" (Sberbank PJSC annual report, 2018). The report of the second largest bank in Russia, which is VTB Bank PJSC has a structure like the previously considered report structure of Sberbank PJSC.

Information on the activities of the VTB Bank PJSC relating the Sustainable Development Goals implementation is reflected both in the annual report and in the report on sustainable development. The sustainable development section of the VTB Bank PJSC annual report for 2018 presents business performance of the bank in such areas as personnel development, social projects and resource management (VTB Bank PJSC annual report, 2018).

After analysis of the reports published by banks for the reflection of the results in the context of sustainable development, we note that banks began to publish annual nonfinancial reports and fund programs in various areas of society development. Thus, sustainable development, presented in the form of implementation of the social and environmental responsibility, becomes a property that is inherent in the modern State, modern enterprises and organizations and, of course, the population presented by civil society. At the same time, the study revealed two significant problems in the formation of reports on sustainable development by commercial banks: 
1. Since the publication of reports within the framework of the concept of sustainable development in Russia is not mandatory for commercial banks, along with RAS and IFRS, a non-systematic nature of the bank reporting is observed, i.e. banks can show the results of their activities in one area or another or even form reports of a certain category for one reporting period and not carry out a similar systematization of data for another reporting period.

2. The lack of Russia's own standards in the context of principles and indicators of sustainable development affects the indicators reflected in the reports of commercial banks within the framework of the concept of sustainable development, which are basically multidirectional.

Thus, the lack of the general consistency of the reports being published and the presence of multidirectional indicators significantly affect the possibility of the objective assessment of the activities of the banks and the correlation with other banks of the reports published by Russian banks on the concept of sustainable development, to identify changes and development trends and, thus, the possibility of further forecasting the activities of commercial banks in the context under consideration.

\section{Discussion}

To determine the main directions of modeling the reporting of a Russian commercial bank within the framework of the provisions of the concept of sustainable development and elements of its objective assessment, we define the main features included in the system of indicators. Considering the problems of reporting on sustainable development, it is necessary to identify the principles of reporting. Reporting, generated with considering these principles, allows you to identify the degree to which the sustainable development goals are implemented that determine the significance and effectiveness. These include:

$\begin{array}{ll}- & \text { objectivity of results; } \\ - & \text { validity of conclusion; } \\ - & \text { scenario justification. }\end{array}$

Sustainable development reporting is based on the activity result for the period. The scenario forecast should be based on the methods of mathematical indicators modeling and supported by actual assessment of development conditions for the foreseeable future. The management should review all available information that is reasonable and the confirmation of which does not require any efforts from interested parties. In determining the significance of the scenario forecast for the sustainability report, it is necessary to rely on actual conditions and forecasted events. The assessment of possible risk should be an integral part of the reporting. In modern conditions, risk prediction is a complex analytical action, and even under condition of well-being in the country in which the bank operates, forecasting is not always appropriate. It is enough 
to cite as an example the events of December 2018 in France, which negatively affected the financial sector of the Fifth Republic.

The economic downturn leads to unemployment, it is expected that this factor should be considered when determining the recoverability of the lending portfolio issued to individuals. Information cannot be excluded because it is unlikely or will occur in the distant future, but at the same time excessively speculative scenarios should not be considered. Management should strike a balance between the risk of excluding unlikely events and including too speculative events based on little or no evidence, and properly document this risk.

The number of scenarios should depend on several factors, such as the type of bank's financial asset, economic conditions and objective impact factors. Management must consider the fact that the percentage change in the macroeconomic scenario may be disproportionate to the change of, in particular, the credit loss. For example, a 10\% increase in unemployment may increase a credit loss two or even four times. The entire range of scenarios and the non-linear nature of the dependency must be constantly re-evaluated to ensure that changes are properly reflected in the model. Estimates should be reviewed for each reporting date. Large Russian banks in practice use three scenarios and make forecasts for three to five years ahead. At the same time, forecasts for five years are considered less reliable.

By creating, for example, a credit model of a bank, the forecast information can be provided either in the credit model (by adjusting the probability of default), or in the form of an adjustment proposed by management. There is no clear answer to the question, and organizations can use different methods, and different methods can be applied to different assets. In practice, most organizations would rather adjust the credit model. Management should ensure the consistent inclusion of forward-looking information without its duplication.

From the point of view of banking activities social and environmental aspects of sustainable development can be called an asset, which is largely formed based on an assessment of previous periods and a forecast of intentions. However, the forecast scenarios of indicators of social and environmental criteria for sustainable development also need a reasonable assessment. At the same time, the existing destructive mechanisms affecting a financial asset have an equal effect on social and environmental ones.

Country studies of the World Bank Group, based on modern conditions, show that the time mark is set to 2030. The Atlas of the Sustainable Development Goals-2018 is a guide to key trends in the development of bank reporting in the context of sustainable development (Atlas of Sustainable Development Goals, 2018). The Atlas used materials from the World Bank Group: world development indicators, a database of observations, many of which are more than 50 years old. 
Figure 4. The standardized model of the sustainable development report (compiled by authors).

\begin{tabular}{l} 
Bank management's letter \\
- Description of development strategies \\
- Results assessment \\
- Ainancial and economic performance of a business \\
- Assessment of rating positions in the credit market, external and internal \\
- Analysis of financial indicatorss \\
- Risk assessment \\
\hline Analysis of socially-oriented activities \\
- Assessment of internal conditions for working with staff, corporate responsibility \\
- Involvement in social projects at the regionaland national level \\
\hline Analysis of bank involvement in environmental projects
\end{tabular}

Speaking about Russian realities, it is important to note that each Russian bank has its own vision of a sustainable development reporting model. At the present stage, there are no uniform principles for building statements, which gives reason to argue about the need to implement a single model (Figure 4).

The presented model is a standardized form used by Russian banks, with each bank forming its own criteria and indicators for evaluation. The financial and economic bloc is assessed in accordance with modern requirements for the banking sector the criteria of the Central Bank of the Russian Federation. The Bank of Russia constantly monitors the activities of credit institutions, thereby reducing the risk of bankruptcy and the advent of a crisis. Situation with the financial and economic conditions reflected in the report of the goals of sustainable development everything is quite clear, but the criteria for the other blocks in the model under consideration are not uniform, and therefore cannot provide an objective assessment. Such conclusions give reason to argue about the need to introduce common criteria for commercial banks reporting in the concept of sustainable development, that is, within the framework of social and environmental significance.

A universal criterion methodology allows to determine the effectiveness of commercial banks as a part of participation in the set of events related to the sustainable development. It our opinion sustainable development goals in relation to reports published by commercial banks can be built based on internal and external criteria, which are presented in Figure 5. Given the comprehensive nature of the SDGs, one of the priority orientations reflected by banks in their reporting is cooperation with international organizations, initiatives of development institutions, state bodies and private organizations on a bilateral and multilateral basis, through the execution of partnership agreements, both in order to fund projects aimed at development of the Russian 
economy and promoting the interests of the SDGs in Russia, and to exchange experiences and best practices with foreign partners.

Figure 5. Criteria for bank activities aimed at the achievement of the SDGs (compiled by authors).

\section{External criteria}

the provision of professional services: the implementation of projects aimed at the improvement of efficiency and the formation of accessibility, the introduction of new services that meet the needs of the banking business in the realities of the development of modern technologies;

provision of social and environmental investments;

participation in social and environmental projects.

\section{Internal criteria}

increasing the amount invested in social responsibility;

inclusive employment policy;

increasing awareness about the need for health care (access to quality healthcare services);

global cooperation with society, businesses and state bodies: participation and

membership in initiatives, associations and forums on economic, social and environmental development;

"Green Agenda": the introduction of sustainable resource consumption practices, reducing the amount of energy consumed in terms of one employee (per unit area).

\section{Conclusion}

The transformation of bank reporting in the framework of the concept of sustainable development is becoming an urgent research and real-world problem. The Sustainable Development Goals implementation provides a unique opportunity to improve interaction and raise awareness about the activities of banks. The global banking community lays special emphasis on sustainable development reporting and pays attention to the importance of using this information, both in practice and in reporting.

Integration of the Russian banking system into the international system for supporting sustainable development is an objective necessity. Accordingly, there is the task to form a unified reporting criteria form for Russian banks in accordance with the goals of sustainable development in the framework of social and environmental activities. The development of efficiency criteria for each block will be an effective way to promote the national banking system towards international requirements for banks.

\section{References:}

Basar, S. 2019. Green Bond Issuance May Reach \$250bn in 2019. Available online: https://www.marketsmedia.com/green-bond-issuance-may-reach-250bn-in-2019/.

Bobylev, S., Perelet, R. 2013. Sustainable Development in Russia, Russian-German Environmental Information Bureau, Berlin-Saint Petersburg.

CBR. 2019. Russian banking sector's review. Available online: http:// www.cbr.ru. 
Dettling, S. 2019. 130 banks holding USD 47 trillion in assets commit to climate action and sustainability. Available online: https://www.unepfi.org/news/industries/banking/130banks-holding-usd-47-trillion-in-assets-commit-to-climate-action-and-sustainability/.

Holder, M. 2019. Green bond milestone: Global issuance surpasses $\$ 100$ billon in first half of 2019. Available online: https://www.greenbiz.com/article/green-bond-milestoneglobal-issuance-surpasses-100-billon-first-half-2019.

Issakova, S.A., Moldabekova, A.S., Kenzhebayeva, M.T., Alibekova, V.N., Tuleyeva, G.T. 2017. Preparing consolidated financial statements in accordance with IFRS. European Research Studies Journal, 20(3), 458-469.

Principles for Responsible Banking. 2019. Available online: https://www.unepfi.org/wordpress/wp-content/uploads/2019/09/PRB-Guidance-Document-Final-19092019.pdf.

Rating of key performance indicators of Russian banks. 2019. Available online: https://www.banki.ru/banks/rat-

ings/?SEARCH NAME=\&SEARCH REGN=\&search\%5Btype\%5D=name\&sort pa ram=rating\&sort order=ASC\&PROPERTY ID=10\&REGION ID=0\&date $1=2019$ 08-01\&date2=2018-08-01\&IS_SHOW_GROUP=0\&IS_SHOW_LIABILITIES=0\#search_label.

Rupeika-Apoga, R., Zaidi, H.S., Thalassinos, E.Y. and Thalassinos, I.E. 2018. Bank Stabil ity: The Case of Nordic and Non-Nordic Banks in Latvia. International Journal of Economics and Business Administration, 6(2), 39-55.

Sberbank PJSC Annual report. 2017. Available online: https://www.sberbank.com/common/img/uploaded/files/pdf/yrep/sberbank_annual_report_2017_rus.pdf.

Sberbank PJSC Annual report. 2018. Available online: https://www.sberbank.com/common/img/uploaded/redirected/com/gosa2019/docs/sberbank-annual_report_2018_rus.pdf.

Semenyuta, O.G. 2017. Green banking as a component of the sustainable development model. Proceedings of the international discussion platform "Black Sea-Caspian Cooperation Forum: Security | Sustainability | development, October 6, 621-624.

Semenyuta, O.G., Dudko, K.V. 2015. Sustainable socially responsible banking business as a new model of banking development. Financial Research, 4(49), 120-122.

The Sustainable Development Goals. 2015. Available online: https://www.un.org/sustainabledevelopment/ru/sustainable-development-goals/.

UN PRI. 2019. UN Principles for Responsible Investment. Available online: https://www.unpri.org/.

UNEP. 2019. United Nations Environment Programme. Available online: https://www.unenvironment.org/.

VTB Bank PJSC Annual report. 2018. Available online: https://www.vtb.ru/akcionery-i-investory/raskrytie-informacii/godovoj-i-socialnyj-otchet/.

World Bank Group. 2018. Atlas of Sustainable Development Goals. From World Development Indicators, available online: https://optefau.files.wordpress.com/2018/06/9781464812507.pdf.

World Bank Group. 2018. Atlas of Sustainable Development Goals. From World Development Indicators, available online: https://optefau.files.wordpress.com/2018/06/9781464812507.pdf. 